\title{
Comics and CLIL: Producing quality output in social sciences with Hergé's The Adventures of Tintin
}

\author{
Cómics y CLIL. Propuestas innovadoras en Ciencias Sociales con \\ Las Aventuras de Tintín de Hergé
}

\author{
Josué LLULL ${ }^{1}$ \\ Centro Universitario Cardenal Cisneros \\ (Alcalá de Henares, Spain)
}

\begin{abstract}
Comics are a significant product of mass culture that reflect the values and models of contemporary societies. Beyond their original function for entertainment, many authors (Hutchinson, 1949; Cary, 2004; Yang, 2006; Bitz, 2010; Ravelo, 2013) have pointed out the potential of comics as a motivating resource for a wide range of educational purposes. Therefore, the use of comics has been extensively applied to increase literacy, promote creativity, develop critical thinking, and reflect on cultural and social values. This paper is intended to draw attention to the didactic possibilities that the Tintin comic books can have for learning social sciences, based on a CLIL classroom experience that has been developed over the last two years in one of the Primary Education degree programmes at Cardenal Cisneros University College, in Alcala de Henares, Spain. The study concludes that comics can be used not only to motivate and facilitate the learning process but also to generate new didactic proposals based on the interaction between texts and visuals. These types of proposals can be particularly helpful to teach curricular contents through a foreign language, such as is the case in bilingual contexts.
\end{abstract}

Key Words: comics; social sciences; teacher training; soft/hard CLIL, Tintin.

\section{Resumen}

Las historietas son un producto importante de la cultura de masas que reflejan los valores y modelos de las sociedades contemporáneas. Más allá de su función original para el entretenimiento, muchos autores (Hutchinson, 1949; Cary, 2004; Yang, 2006; Bitz, 2010; Ravelo, 2013) han señalado el potencial del las historietas como recurso motivador para una amplia gama de propósitos educativos. Por consiguiente, el uso de historietas ha sido ampliamente difundido para aumentar la alfabetización, promover la creatividad, desarrollar el pensamiento crítico y reflexionar sobre los valores culturales y sociales.. Este articulo tiene por objeto llamar la atención sobre las posibilidades didácticas que las historietas de Tintín pueden tener para el aprendizaje de las ciencias sociales, sobre la base de una experiencia en el aula AICLE que se ha desarrollado en los últimos dos años en uno de los programas de grado de Educación Primaria en el Centro Universitario Cardenal Cisneros, en Alcalá de Henares, España. El estudio concluye que las historietas pueden ser utilizados no sólo para motivar y facilitar el proceso de aprendizaje, sino también para generar nuevas propuestas didácticas basadas en la interacción entre los textos y las imágenes. Este tipo de propuestas pueden ser particularmente útiles para enseñar los contenidos curriculares a través de una lengua extranjera, como es el caso en los contextos bilingües.

Palabras Claves: historietas; ciencias sociales; formación de docentes; AICLE suave/duro, Tintin.

\footnotetext{
${ }^{1}$ The author would like to acknowledge his university colleagues for their support and valuable suggestions, especially as provided by Matthew Johnson, James Crichlow, and Raquel Fernández.
} 


\section{INTRODUCTION}

\section{The medium of comics}

A comic is a graphic story that integrates both iconic and literary codes in a narrative or chronological sequence through the combination of pictures, texts and signs. It is difficult to establish a more precise definition due to the great difference in the meaning and the applicability of this concept in every language and country. As a result of this, no consensus has been reached on a definition of the comic medium.

Most authors emphasise the combination of text and images, however there are some outstanding examples of pantomime comics. The Englishspeaking tradition mainly focuses on the idea of the graphic novel, that is, a sequence of consecutive images to recount a story. According to this idea, the famous cartoonist Will Eisner (1990) described comics as "sequential art", which arrange pictures and words to narrate a story or dramatize an idea. In contrast, McCloud (1993) downplayed the importance of language by defining comics as "juxtaposed pictorials and other images in deliberate sequence, intended to convey information and/or to produce an aesthetic response in the viewer" (p. 9). In contrast, Harvey (1994) insisted that "the essential characteristic of comics is the incorporation of verbal content" (p. 4). In spite of the real weight of each element, this semantic code that combines static images and textual language is the fundamental essence of comics.

One of the most significant aspects concerning comics is their capacity to transmit messages that may be connected to reality, but can also be fictional or satirical. In this case it is worth revising comics as a powerful vehicle of communication. On the one hand, comics are essentially iconic depictions and thanks to their visual metaphors they can be easily understood without the help of words; on the other hand there are some beautiful examples of comics that should be appreciated as little wonders of literature.

Another point is the aesthetic value of comics and their inspirational strength for twentieth-century art. The massive circulation of printed copies of cartoons contributed to the spread of symbols, characters and stories that eventually became the basis of popular culture in the 1950s and 1960s. As a result, comics can have a number of implications regarding their own specific meanings, but also their more or less evident references to reality or to certain 
contemporary events. Ramírez (1998) and Eco (1995) added that comics are a typical product of mass culture and so they transmit the ideas, myths and values of any society, acting as a very influential part of informal learning. Thus, comics always have various levels of significance and they are truly fascinating for several concerns.

Probably the most important reason for that fascination is the touching atmosphere that the comic medium provides. The interrelation of appealing pictures, short texts and point-blank signs makes comics entertaining and easy to read. There are several elements involved in the way a comic is depicted (Barbieri, 1993). Some visual elements to be considered are the size, shape and placement of the frames, the kind of shots, the angles of view, the line, the presence or absence of colour, the figures, and the settings. Some verbal elements to take into consideration are the plot and its sequence, the way the story is encapsulated, the amount of text inserted, the combination of narration and dialogue by using captions or speech bubbles, the typography, and the introduction of onomatopoeias or sound effects. The integration of both, visual and verbal, provides the format, composition and artistic values for each comic.

\section{The use of comics in education}

The use of comics in Education has been extensively pointed out in specialised literature. They are frequently brought into play to foster more effective student engagement in the teaching-learning process. Cartoons have an almost magnetic attraction for youngsters, and therefore it can be really motivating to present any topic through this medium.

Comics started to be introduced in schools in the USA since Hutchinson's pedagogical experiment (1949). Among the observed results, it was valued that comics could increase imagination, emotional intelligence, empathy and critical thinking. Then, comics started to be used to develop reading skills, as well as preventing students' fear of books and introducing them to the field of serious literature. The followings are cases in point: Don Quixote and most of Shakespeare's plays have been adapted into comics. This is because narrative and descriptive techniques, dialogue sequences, vocabulary and idioms can be rapidly taught through comics. In other words, comics can precede the reading of more canonical literature (Versaci, 2001). As the Spanish cartoonist Ibáñez claimed, Mortadelo can be a preparatory step before facing Salgari, Verne, or even Kafka. 
Nowadays, many pedagogues even encourage including a collection of comic books in the school library (Karp \& Kress, 2011).

Gene Yang (2006) summarized the strengths of comics as an educational tool by highlighting five characteristics.

- Motivating: The most positive benefit of comics is their capacity to stimulate students for many subjects. As has been proved by many researchers, the students can learn in an easier, more fun and interesting way when using cartoons.

- Visual: Being a pictorial medium, comics have an advantage over other teaching materials because the content is more easily achieved when illustrated. Putting a human face on a given topic provides an emotional connection between that one and the students. Besides, visual learning is on the trend towards teaching to multiple intelligences as accepted by educators today.

- $\quad$ Permanent: This feature concerns the idea of how in comics, the language and visuals remain static, whereas they are fleeting in films and animation. With comic books, the passage of time and assimilation of information progress as fast as the reader moves his eyes across the page. This visual permanence can be especially useful for classes of English as a Foreign Language.

- Intermediary: Yang says that comics can serve as an intermediate step to difficult contents, principally for students who do not enjoy reading. Working on comics may be the starting point to reach posterior critical thinking tasks or also to deal with higher topics. Moreover, comic-based cross-curricular projects involve a plethora of skills and activities.

- $\quad$ Popular: As comics are a prominent expression of contemporary culture, it is a good idea to incorporate them into the syllabus. By working on comics, teachers could bridge daily school issues with real life. In addition, the use of comics promotes media literacy and persuades students to become critical consumers of popular media messages.

In essence, reading comics is a straightforward way not only to increase an assortment of multiliteracies, as defined by Winch et al. (2010), but also to know what society is about. Regarding the first aspect, it is supposed that comic texts are shorter and more simplified than other literary texts. Nevertheless, Jacobs (2007) considers comics also to be complex and multimodal texts, which can 
engage students in multiple literacies in order to foster reading comprehension in the classroom and beyond. Likewise, Cary (2004) emphasises how the reduced texts of many comics make them manageable and linguistically beneficial for even beginning level readers, as they can supply language-learning opportunities for everybody. Furthermore, the "permanent" condition of the language in comics, previously noted by Yang, permits the reader to focus on words and sentences in an exhaustive way, which eventually helps understanding. Finally, as texts are linked to images, language comprehension is easier because the reader can infer their meaning by contextualisation.

All this is especially important when learning a foreign language, as expressed in the following anecdote. A doctoral scholar in Literacy and Cultures at Berkeley University, California, diminished a student's reluctance to Spanish language by giving the opportunity of reading Tintin comics (quoted by Cary, 2004, p. 65):

I tutored a Spanish Immersion student, an English speaker, going into third grade a couple of summers ago. His favorite books in the world were Tintin. He was a very reluctant Spanish speaker-could do it, but claimed to "hate" Spanish. So I found him Tintin in Spanish, and he just had the best time figuring out who all the characters were and what the catch-phrases and jokes were in Spanish. It was the most motivated I'd ever seen him. His mom said he even voluntarily picked it up, which never happened with any other Spanish text. I Xeroxed a few of the strips, whiting out the print, and had him write them. He enjoyed that too, and especially wanted to go back and compare what he'd written to the "real" words.

School textbooks usually include comic strips to illustrate certain contents in some subjects. The aim is, once again, to make easier and more attractive some aspects of the teaching process. Nevertheless, it is less frequent to find educational experiences dealing with comics as the leitmotif of the whole didactic program. In Spain, the Asterix Project may be mentioned with regards to encouraging reading among students. Due to its inventiveness, the project received a national award of research and innovation by the Spanish Ministry of Education (Mondéjar Mateo, 2006). The use of comics in schools is also frequent for EFL classes; so they appear in textbooks and other didactic materials. However, the strips display ordinary communicative situations and the core topic is exclusively focused on the language aspects. 
Probably one of the most remarkable experiences is The Comic Book Project, an enterprise founded in 2001 by Dr. Michael Bitz in New York. This is an artbased literacy program aiming to engage children in a self-organised and multidisciplinary creative process. The process includes several tasks associated to planning, writing, designing and publishing original comic books that are widespread on the Internet (see http://www.comicbookproject.org) to be used as learning and motivational tools for other children. Bitz (2010) explored the potential links between graphic narratives and literacy learning in order to achieve youth development. The topics of this project go further than language and deal with environmental awareness, pollution, conflict resolution, bullying alertness and migration among others. The experience has been so successful that it has expanded all over the USA and more countries such as Canada, Mexico and Nicaragua.

Another example is The Comic Book Initiative managed by the Department of Education of Maryland partnered with Diamond Comic Book Distributor since 2004. As explained on its website, this project is justified by the necessity of encouraging reluctant readers to read more and gifted students to foster their knowledge and creativity. Their goal is to develop a global literacy plan by means of designing didactic strategies to support the use of graphic literature at every educational level.

To conclude this section, comics can be valued not only as a motivating material for children and youngsters but also as a powerful communication vehicle, an important cultural expression and a creative resource for a wide range of educational purposes.

\section{A teaching proposal based on The Adventures of Tintin}

A common criticism is that the majority of comics represent events and situations in a less rigorous way and this may be a possible handicap for their use in education. However, some comics are inspired by true stories and are intended to present critical views on topics such as about politics, economics, and social problems.; even if these are fictional they may lead to discussion. Thus, the question is to consider whether comics can be a valid tool for learning academic content.

Ravelo (2013, p. 4-5) summarised an interesting reflection about the possibility of lecturing history through any fictional narration. According to 
various authors, it is important to differentiate between historiography and interpretations about history. Historiography is a number of validated narrations based on the analysis and critical study of real data provided by historical sources; interpretations are understood as non-scientific comments on historical facts and they can include parts of fiction as well as criticism, personal opinions or even satire. Comics are of course included in the field of interpretations because they propose a fictional representation of reality. But Ravelo argues that they can be a medium to represent historical facts as valid as any other which is derived from what might be perceived as more serious genres. In addition, she proposed a unit of work to teach about the Jewish Holocaust through the Art Spiegelman's Pulitzer prize-winning comic Maus (1991).

On his behalf, the Spanish philologist Lillo Redonet (1995) suggested many fictional comics that can be used to teach about classical culture in secondary school. He cited the worldwide known Asterix series, created by the writer René Goscinny and the artist Albert Uderzo in 1959, but also other comics similarly inspired by the Roman Empire era.

Comics are indeed an excellent way to approach History. Besides, they are an eye-catching didactic resource to make students positively involved in the learning process. However, it is important to use them critically in order to compare reality and fiction, but also to be aware of the distorted (or even incorrect) information appearing in the comics we are going to work on. This basic criterion must be taken into account in the same sense for other sorts of visuals that are employed in teaching and learning within the field of Social Sciences. For example, movies, animated pictures, cartoons, virtual reconstructions and video games can also be used to illustrate historical facts, characters and sceneries, but their visual proposals are sometimes controversial. To conclude, it is crucial for teachers to maintain the correct balance between the innovative use of these types of resources and their fundamental obligation to transmit scientific knowledge adequately.

The present article revolves around an educational project that has been developed over the years 2012 and 2013 in the Cardenal Cisneros University College. This Higher Education centre is administratively linked to the University of Alcalá, Spain and specialises in pedagogical studies, offering degrees in Teacher Training, Psychology and Social Education, in addition to a number of Master's courses, a virtual campus for on-line students and a wide range of socio- 
cultural activities. Since 2008, the Cardenal Cisneros University College has been developing a bilingual program as a response to the current educational demands in Spain. After a period of specific training and coordination, this bilingual program was launched in 2010 (see Johnson, 2012). Twelve lecturers and three native language assistants have been involved in the implementation of the program with the support of external counsellors and other academic institutions. The final goal is to learn between a third and a half of the total number of formative hours in every degree through the English language. However, the use of English as the medium of instruction is designed to be progressive, less in the first years and more in the last ones.

The learning process in bilingual subjects is based on the CLIL educational approach. One of the chosen subjects within this itinerary is the "Didactics of the Social Sciences" which is imparted in the first term in the third year of the degree. This subject is intended to get students to know and evaluate the multiple educational resources they could apply for teaching Geography, History, Art History and other disciplines related to the study of culture and society. As part of their learning outcomes, teacher trainees must produce innovative materials and didactic proposals that could be hypothetically applied in a bilingual classroom of Primary Education. That was the seed of what we called The Tintin Project, which was considered part of the students' continuous assessment and accounts for a $20 \%$ of the final grade in the subject.

Compared to other comics, the Tintin series is better adapted to the Primary Education cognitive level, so this is why it was chosen as a centre of interest for the subject. Tintin was created by the Belgian cartoonist Hergé (Georges Remi), for a youth supplement launched by the newspaper Le Vingtième Siècle in 1929. He immediately became a very popular character, especially in Europe. Apart from its fascinating and well documented story lines, the comics have been admired for their "clear line" style of drawing which allows Hergé to depict very clean, expressive cartoons. This way of painting was strongly influenced by the Japanese picture cards as well as by other artists such as the French illustrator Benjamin Rabier, the Art Deco designer René Vincent, and the American cartoonist George MacManus. Hergé's work has also been said to be reminiscent of surrealism and other avant-garde styles (Goddin, 2008).

A huge part of twentieth-century history is displayed in the collection of twenty-four Tintin comic books (Farr, 2001). The ever-young protagonist, who 
works as a reporter for a Belgian newspaper, travels all over the world and goes through time, becoming a privileged witness of many social situations and historical events. He is also a philanthropic human model inspired by some of the best moral values of Western civilisation (Castillo, 2011). During his adventures, Tintin is involved in various types of stories and situations, including political thrillers, spy plots, cultural clashes, and economic crisis. Gravett (2005) defends the authenticity of the Tintin stories by presenting a quote from Hergé explaining how thoroughly he researched the creation of the book The Blue Lotus (1936):

It was from that time that I undertook research and really interested myself in the people and countries to which I sent Tintin, out of a sense of responsibility to my readers. (Hergé, quoted in Gravett, 2005, p. 152)

As a consequence, there are a huge number of well-documented historical and socio-cultural topics that may be taught through the Tintin comics. The challenge for us was to read and work with The Adventures of Tintin in English with the aim of integrating content and language within a bilingual context.

\section{METHODS}

As I mentioned before, The Tintin Project was a core part of the academic work conducted in the subject "Didactics of the Social Sciences" according to the CLIL educational approach. The target group was composed of one hundred students in total, aged between 20 and 25 years. They all were bilingual teacher trainees in the Cardenal Cisneros University College and their English level was in most cases B2, according to the Common European Framework of Reference for Languages. Since they were in the third year of the degree, they had already received formation about general didactics, English language and CLIL.

Before the project was launched, the teacher of the subject introduced several topics related to cultural anthropology, the history of human civilization, models of social organisation and human geography. A plethora of didactic suggestions and resources were also provided to reflect on the multiple possibilities of teaching and learning about these topics in Primary Education. This part was strongly connected to the analysis of the official curriculum for that educational level, as described in the Spanish Laws of Education promulgated in 2006 (Ley Orgánica 2/2006 de Educación; Real Decreto 1513/2006 de Enseñanzas Mínimas de la Educación Primaria). These documents list the 
minimum contents to be taught in schools for 6 to 12 years old children and are very relevant for any subject matter in the teacher training degree. One of the particularities in the Spanish Primary Education is that both the Social Sciences and the Natural Sciences are integrated in the same area with a wide crosscurricular perspective. ${ }^{2}$ According to the mentioned laws, the contents included in this area are grouped into seven blocks, which are: 1) the environment and its conservation; 2) living things; 3) health and personal development; 4) peoples, cultures and social organization; 5) changes through history; 6) matter and energy; 7) objects, machines, and technologies.

To sum up, every student enrolled in the subject is required to explore the multifaceted relationship among man, culture, nature and society. In addition they are pushed to imagine different ways of learning about this. The Tintin Project was a general framework to think about the possibility of teaching Social Sciences topics through comics and its objectives were as follows. By the end of the project the teacher trainees should be able to:

1. Consider the didactic possibilities of using comics in the classroom.

2. Research about some socio-cultural topics appearing in the Tintin comics.

3. Produce didactic activities or materials related to the Tintin comics with the aim of teaching Social Sciences in Primary Education.

4. Plan different types of scaffolding to facilitate the comprehension of comics in English.

Classroom management was organised according to four distinctive types of groups: theoretical classes for the whole group, practical classes for half of the group, seminars for small groups and tutorials to support project work. One theoretical class was used to present a general overview and vocabulary about the comic medium and the Tintin series. Besides, it was given a general explanation about the project, its objectives, guidelines, agenda and assessment criteria. All this information was also available in a written document uploaded to the university intranet.

A couple of practical classes were aimed to show how to work with Tintin comics from a CLIL perspective. To do this I prepared a CLIL activity focused on a comic strip taken from the book Tintin in Tibet (1960, p. 7) which depicts a

2 The current conservative administration of Spain is conducting now an educational reform that is intended to divide this area into two subjects, social sciences and natural sciences, as it was before 1990. Thus, the organization of the curriculum will change significantly in the future. 
curious anecdote about a cow in Delhi city. For Hindus, cows are sacred and cannot be disturbed in any way, but one of the characters in the story argues about this when a cow is blocking a street. The activity was designed with a particular type of instructional scaffolding called "contextualizing" that leads a careful progression from a context reduced to a context embedded. Students first worked on the vignettes with the speech bubbles in blank in order to talk and guess what was happening. The following questions were proposed to guide the discussion:

- In which country is the story happening?

- What are the characters doing?

- What are the main differences between the Western characters (Tintin and Captain Haddock) and the native Indian people respect to clothes, behaviour, etc.?

- What do you think the represented discussion is about?

Afterwards pupils had to imagine a possible dialog for the story and write it down inside the speech bubbles. In the end they could compare their writing to the original text in the Hergé's comic book. During this stage students were supposed to use HOTS (higher order thinking skills) because before having the real dialogue they had to generate a hypothesis and predict what the problem was. Right after students were invited to look for further information about Hinduism and Indian traditions. It was permitted the use of tablets, laptops and mobile phones in the classroom so that the students could access rapidly to the subject materials in the university intranet and other data from selected websites. The subsequent sharing made possible not only to contrast information critically but also to comprehend the background of the comic narration.

The next step was transferring the story to other real situations in which a similar problem can occur. Obviously, the anecdote with the cow exemplifies what cultural clash is, because it shows different customs and behaviours. It also helps students to go deeper in the interpretation of cultures. The case of the Indian cows has been studied by anthropologists in the sense of how symbols have a very significant role in constructing public meaning. However, Harris (1975) provided a materialist explanation for this set of beliefs by suggesting that it is economically adaptive. The teacher provided a theoretical explanation about this and reviewed the cultural aspects represented in the vignettes from the perspective of the anthropology. To sum up, the analysis of a comic strip 
provided a fun opportunity to interconnect cognitive elements with the subject contents. Moreover, it trained the students to analyse comics critically and look for reliable sources of information.

For the next classes students were divided into small groups and encouraged to work together in a number of seminars and group tutorials for a two months period. The working plan followed "The CLIL Pyramid" that suggests four basic steps, as described by Meyer (2010, p. 24). According to this schema the teacher proposed in the first seminar session an overall topic to start thinking and suggest a general outcome, in order to create a working plan. The topic was "Teaching Social Sciences through comics" and the expected outcome was designing didactic proposals related to the Tintin comic books for teaching History, Geography and other Social and Cultural aspects to children. Secondly, a rich, multimodal input was provided through different media, materials and scaffolding techniques, aimed to activate language skills, discuss the instructive potential of comics and plan each step of the tasks. To this end, in the same seminar session, the teacher showed specialised articles, websites, comic strips and cartoons, which were to be commented on. All this was carried out with the support of a native language assistant who monitored the students' work.

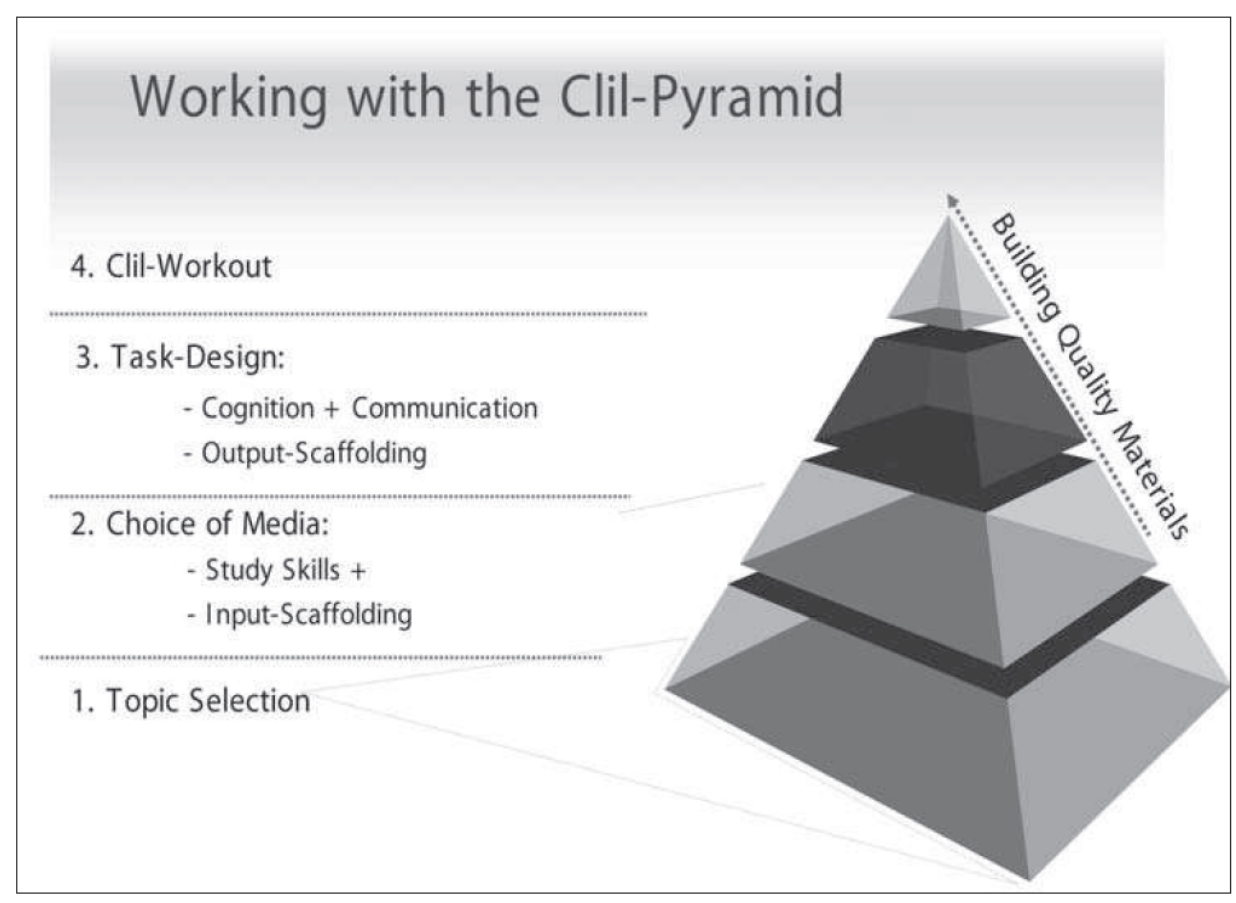

Figure 1. The CLIL pyramid (๑ Meyer, 2010). 
The task-design took place in the third step of the CLIL Pyramid, which coincided in the calendar with the time around the second seminar session. This phase was centred on planning research activities, sharing information and eventually generating a didactic proposal in relation to The Adventures of Tintin. Students were required to read one of the comic books in English, choose one historical, geographical or socio-cultural aspect and look for further data about it. Some possible working topics were suggested in a supplementary document provided by the teacher who was also available for tutorials during the process. In this stage, pupils had to broaden their knowledge, trigger their higher order thinking skills and develop critical interaction in different ways. All these aspects were continuously assessed.

Finally, the CLIL-workout was determined in the last step of the pyramid coinciding with the last seminar session in the term. In that seminar students had to give a draft presentation about their workout with the aim of being preevaluated by their classmates, the teacher and the language assistant. The idea was to check what they were doing and also receive suggestions to improve their work. Thanks to this it was easier to understand what their final goal should be in relation to the assessment criteria.

Students were expected to achieve two different outcomes. The first one was a paper written in English that had to include two items. On the one hand some theoretical research about the main data and features of the selected topics; it was especially important for the students to justify the instructive importance of those topics according to requirements of the Primary Education curriculum. On the other hand, they had to design a long-term didactic project in relation to those topics to be implemented in English for Primary Education; this project had to use the Tintin comics in any way as a didactic resource and of course must include the usual items in any didactic plan (objectives, theoretical justification, a description of the supposed target group, content syllabus, methodology, activities, timing, resources and assessment plan). A checklist model used for the final assessment of this paper is available in the Appendix.

As a second outcome, each student was required to give a public presentation in English for the rest of their classmates with the aim of showing the main conclusions of the whole process. The series of presentations took place in the last week of the semester and their format was flexible. Students were allowed to prepare materials such as PowerPoint presentations, enaged in 
workshops, and take advantage of group dynamics; most of them also wore fancy dress and decorated the classroom. In general, most provided a brief introduction to the chosen comic, an explanation about their teaching proposals, and an exhibition of the handcrafted materials they made for the occasion. In addition, they could implement some instructive activities for their partners that which was an opportunity for cooperative learning. During the presentations both the content and the language skills were evaluated. Creativity, originality, visual support and relation to the chosen comic were also taken into account for the final mark.

I have classified the resulting proposals into two different types of activities: language focused activities and content focused activities. The first type can be linked to what is called "soft" (or "weak") CLIL, whereas the second one is usually named "hard" (or "strong") CLIL, after the suggestions given by Ball (2010).

\section{RESULTS}

\section{Language focused activities ("soft CLIL")}

These types of activities follow a language-driven approach that maybe is a more EFL version of CLIL, because its focus is on linguistic objectives and the content is just a framework to work communicative competences in the foreign language. In this particular case, comic visuals help to promote an intensive use of English by means of the CLIL linguistic progression explained by Coyle et al. (2010, p. 36) with the famous "language triptych". This triptych involves language of learning, language for learning and language through learning and is the basis for scaffolding both language and content achievement in any bilingual program. In relation to this, our didactic proposals worked on single vignettes as well as entire comic strips in order to contextualise and activate communicative skills. So the Tintin comics were used in this segment to activate prior knowledge and apply different ways of scaffolding (modelling, bridging, contextualising, schema building, re-presenting texts and developing metacognition), as described by Walqui (2006).

The language-focused activities that were produced within The Tintin Project may be divided into four different categories, discussed in the following sections. 


\section{Scaffolding techniques}

These were intended to introduce comics in the classroom, motivate the learning process and activate prior knowledge. As an example, the majority of these activities were centred in describing, analysing and commenting comic strips. Other examples include meeting the characters of the comic in a short performance, wearing costumes, projecting selected cartoons on a digital whiteboard, decorating the classroom, showing handcrafted materials related to the comic, providing mysterious clues about the comic's plot, asking questions, and guessing the topic to work on. Most of these techniques were also utilised to introduce curricular concepts, specific vocabulary and language structures that were necessary for the later content-focused activities. In this respect, I would like to remark on a particular handcrafted material created by one group of students: the "Tintionary". This was a set of laminated flashcards, each with a picture and a word to clearly identify significant objects that are depicted in the comics.

\section{Language Scaffolding}
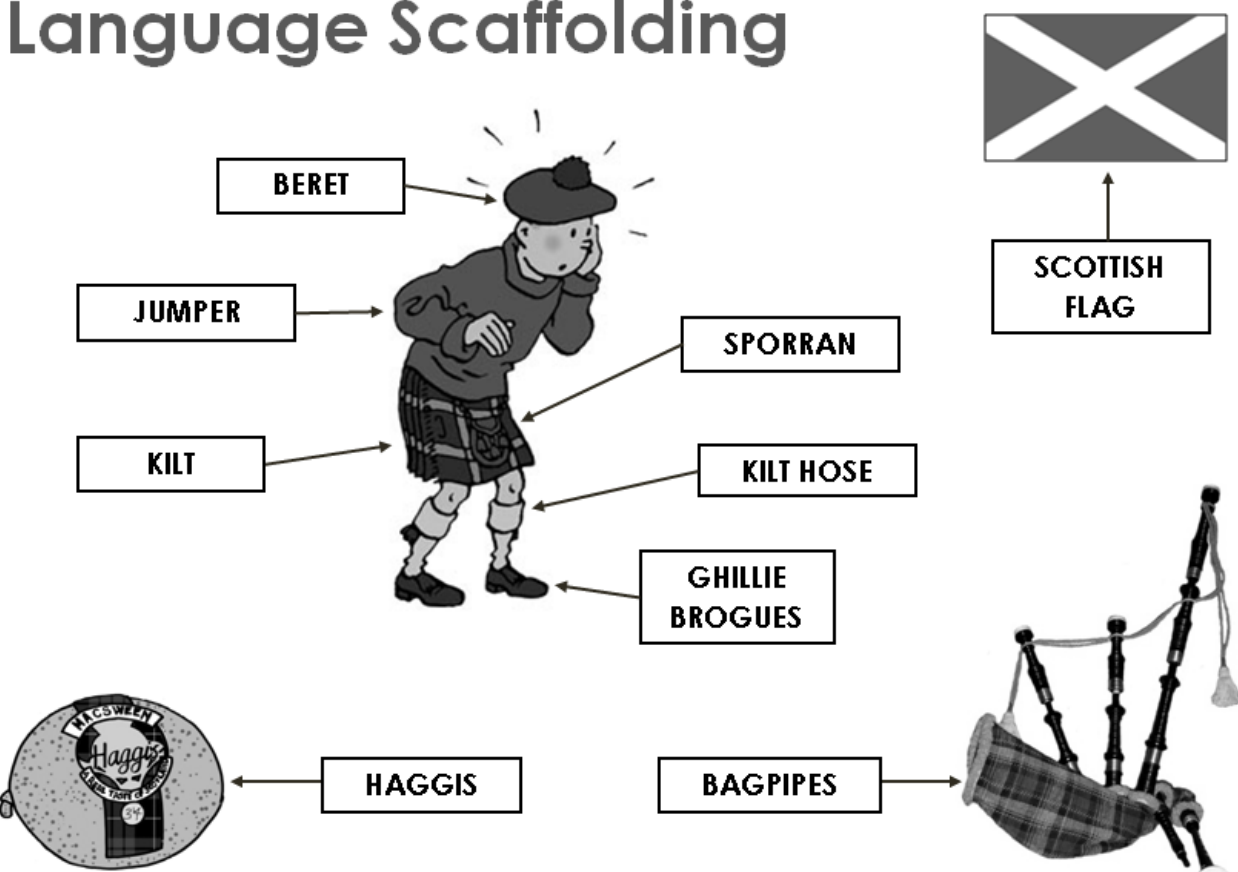

BAGPIPES

Figure 2. An example of scaffolding technique aimed at learning specific vocabulary related to Scottish culture, inspired by the comic book The Black Island(৫ Hergé/Moulinsart 2014). 


\section{Communication activities}

These use cartoons as a tool to make pupils read, write, and talk about the comic itself or about other related topics in order to promote informal conversations and enhance their communicative skills. Visual support helps comprehending the meaning of language expressions, unknown words and even the story script. One very common activity is describing single vignettes by applying some language clues such as "in the foreground ...", "in the background ...", "on the right ...", and "there is...". Another activity is to blank the speech bubbles with the aim of being filled in with likely texts. Activities such as reading selected comic strips, rewriting dialogues, reordering a jigsaw of vignettes according to the correct narrative sequence, quizzes, memory games, decoding texts, and inventing alternative plots provide more communicative possibilities. One group of students created a fascinating activity to learn about emotions by analysing the faces and body language of the comic characters. All the suggested tasks dealt with the three steps of the CLIL linguistic progression contemplated by Coyle, Hood, and Marsh (2010): language of learning (linked to an analysis of the content implied in both texts and cartoons), language for learning (transferable structures and discourse patterns such as narrative tenses, adverbials, and adjectives), and language through learning (related to emergent knowledge that comes from the unpredictable things arising from free activities such as re-writing).

\section{Forums}

The activities included in this group were aimed at reading in detail, analysing, commenting on and discussing each comic book in order to foster literacy. Participants could give their opinions about the characters, the plot and the cartoons as a way of scaffolding each other's understanding. So they are not only language-focused activities; they serve to fully comprehend the sense of the story by means of interpreting content and visuals together. Obviously, the interpretation would be incomplete if the interaction of each cartoon with those previous and following were not taken into account. So, the content of the strips and their layout are two basic parts for the literary analysis of each comic book. The forum was especially useful during the research phase or the project. 


\section{Activities to learn English idioms}

As we realised in the previous section, reading comics is an excellent way to learn any language because of the shortness of the texts and the direct style of the dialogue presented. There is a wealth of common words and expressions that can be naturally understood thanks to the visual context. Another point is to check the English transcription of some exclamations, sounds, noises, and onomatopoeia because they are very different from the way in which they are written in other languages. Furthermore, the Tintin comics are linguistically enriched by the sheer number of bizarre curses and insults frequently uttered by Captain Haddock-for example: "Certified diplodocus", "Gibbering anthropoid", "Macrocephalic baboon", "Ostrogoth", "Pithecanthropic mountebank", or the flabbergasting "Millions and billions of bilious blue blistering barnacles in a thundering typhoon!”.

\section{Content-focused activities ("hard CLIL”)}

These types of activities follow a content-driven approach. This means that learning is focused primarily on the knowledge, so the aim is to learn different subjects through English (Deller \& Price, 2007). Working on this option is especially important for our undergraduate students of Primary Education because teaching English throughout the whole social sciences curriculum is now compulsory in the bilingual schools of Madrid. In this light, comics must be considered as a medium to illustrate, learn or reflect critically about the social and historical situations depicted in each story with the aim of developing cultural awareness (Tomalin \& Stempleski, 1996).

The content-focused activities that were produced within The Tintin Project may be divided into four different categories, discussed in the subsequent sections.

\section{Activities related to geography}

Tintin travels a lot, and it is very interesting to find on a map the location of the real or supposed places that are depicted in each comic book. Tracing Tintin's itinerary in each adventure is another very practical task. The whole of Europe, the USA, South America, Africa, Egypt, the Middle East, the Arab Countries, India, China, and Tibet are just some of the settings of The Adventures of Tintin. 
Other activities are related to the geographical features appearing in cartoons in order to compare them with real photographs. In this kind of activity, single vignettes are used to identify landscapes, climates, landform, biodiversity and human settlements, as well as to infer the characteristics of certain ecosystems, such as deserts, jungles, savannahs, and high mountains.

\section{Activities related to history}

In spite of Hergé's controversial view about some political situations, most of his comic books are inspired by real historical events. For instance, my students used the story of Tintin in the Land of the Soviets (1930) to talk about the Russian Revolution, but there are many other examples: Cigars of the Pharaoh (1934) and Prisoners of the Sun (1949) for ancient civilisations; Tintin in the Congo (1931), The Blue Lotus (1936), The Crab with the Golden Claws (1943), and Tintin in Tibet (1960) reflect on colonisation; Land of the Black Gold (1950) and The Red Sea Sharks (1958) offer an interesting approach to decolonisation, the oil trade, and the rise of the Arab countries; political revolutions, dictatorships and civil wars in Latin America are trending topics for The Broken Ear (1943), and Tintin and the Picaros (1976); fascist expansionism is suggested in King Ottokar's Sceptre (1939); and The Calculus Affair (1956) is a valuable exploration of the Cold War period.

All the aforementioned themes are difficult to teach in Primary Education but they can be illustrated in a motivating way by using comics. Moreover, visuals help to overcome the inherent difficulty in teaching complex contents through a foreign language. This is a core point for our project because it is not possible to rely so much on transmission of ideas in the same way one might in the mother tongue. Thus, the proposed activities mainly focused on contextualising each comic plot in its historical background, taking into consideration its date of publishing. To do this, the teacher first helped the students to identify the historical event or situation described in the chosen comic book and then suggested a specific bibliography to be consulted. Students had to research about that in the university library and hand in a short report to the teacher with a view to discussing in the tutorials. A critical comparison between the fictional stories shown in the comic books and the real facts explicated in the academic bibliography was required as part of the outcome. After all, there are a number of studies that criticise the way Herge portrayed some countries and situations (see Gual Boronat, 2011; Barragán Gómez, 2012). 


\section{Activities related to social aspects}

These activities aim to present social situations, lifestyles, and economic activities appearing in the comics. As an example, mass-media manipulation was introduced in a didactic proposal on The Castafiore Emerald (1963). Other suggestions generated for this objective including comparing rural and urban spaces, identifying means of transport and energy sources, searching for inventions and machines, and noticing hobbies and leisure activities. Through the analysis of government institutions, pupils also noted different political systems and possible causes for revolutions. For instance, in King Ottokar's Sceptre (1939) it is easy to see how a European monarchy works; on the contrary, caricaturised military dictatorships are evidently presented in the stories set in Latin America. Other activities promote a critical view about some illegal forms of trade (e.g. drugs, diamonds, arms, and slaves) and their negative consequences.

\section{Activities related to cultural aspects}

A variety of ethnic groups, cultural traditions, religions, customs, languages, behaviours, and festivities are depicted in the Tintin comics. One of the most highly valued books by my students was Tintin in America (1932); this comic deals with the situation of the Indian reservations and provides a comparison between their primitive lifestyle and the modern atmosphere of industrial megacities. The Blue Lotus (1936) includes a charming scene in which Tintin and a Chinese boy tell each other the truth about a number of cultural stereotypes. Other activities focused on the analysis of the architecture depicted in comic strips. Hergé was very much documented as an illustrator of urban spaces and buildings. Good representations of Arab architecture, Egyptian tombs, Buddhist temples, pre-Columbian monuments, medieval castles, churches, palaces, and skyscrapers are to be compared with real photographs in order to learn about art history. In addition, some comic books deal with archaeological explorations, museums, fake art, and the antiquities trade. Finally, scientific discoveries are core topics for The Shooting Star (1942), Destination Moon (1953) and The Calculus Affair (1956). 


\section{DISCUSSION}

The most important effect of this experience is the increasing awareness of how the teacher and the students together can reflect on the infinite possibilities of comics for education. Children are not used to working with comics in the classroom, but this could be a very motivating option to learn about many subject matters in a different way. After participating in The Tintin Project, my undergraduate students were absolutely convinced of the advantages of using comics in education, although they also believed it was necessary to critically evaluate their accuracy and appropriateness for each case. This is what they expressed in their self-evaluation and conclusions at the end of their papers.

Going back to the initial objectives, we can confirm that the students covered all the knowledge, competences and attitudes proposed in the project. They valued positively the instructive potential of comics, learnt about several socio-cultural topics, produced didactic activities and took into consideration the importance of scaffolding in bilingual education programmes.

Personally, I have to admit that I am really surprised by my students' incredible creativity. Their work went far beyond simply doing a piece of written work and an in-class oral presentation. They included lots of handcrafted materials, group dynamics, games, digital whiteboard resources, blogs and others based on the comic-centred activities; see Figure 3.

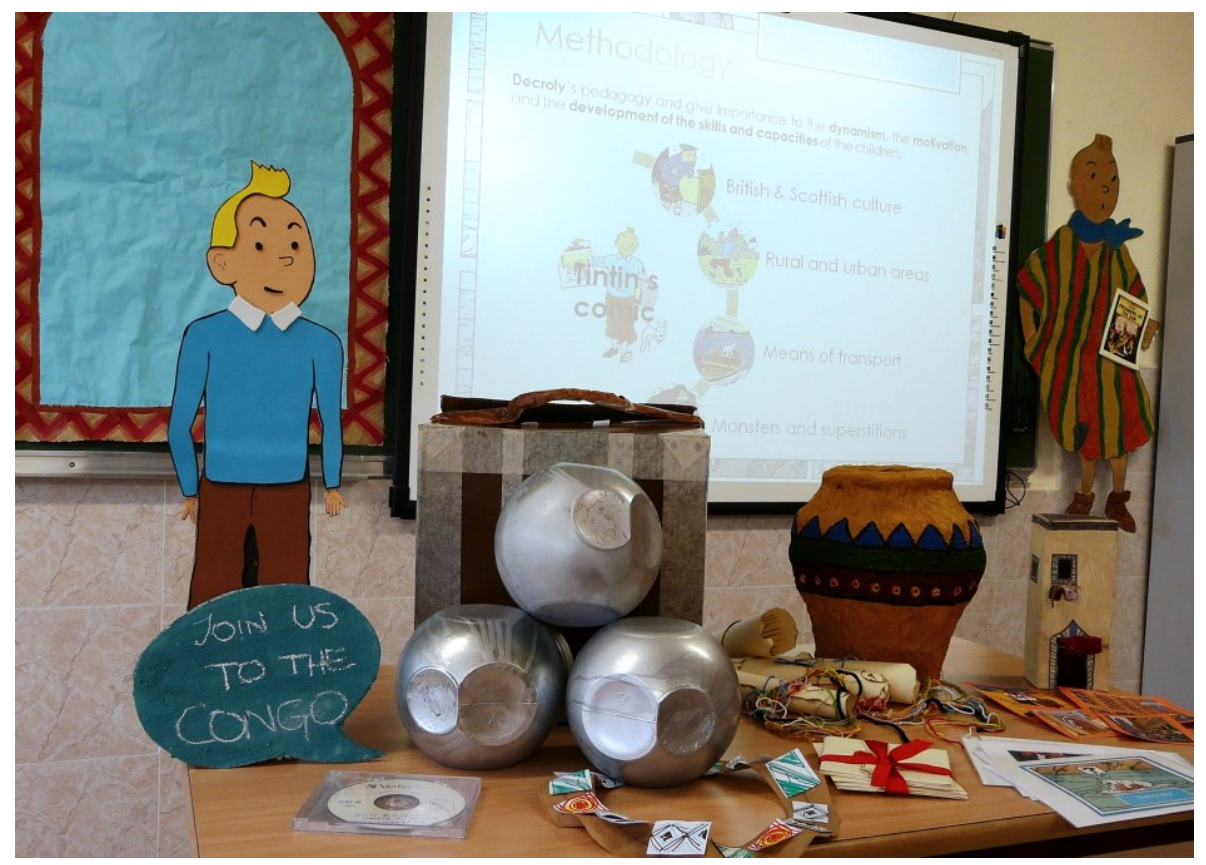

Figure 3. Handcrafted materials created by the students for their presentations. 
This demonstrates the strong relationship between rich, multi-modal inputs and pushed, multi-modal outputs. A motivating rich input can foster student's creativity with the object of building quality materials for teaching and learning. Thus, The Adventures of Tintin have been a nice starting point to enrich the learning environment and think about education in a different way.

Concerning the process, the majority of students participated enthusiastically in the seminar classes and completed the tasks step by step as required. Everybody passed and the majority got a brilliant mark. Perhaps researching the topic presented the most difficulties, whereas the creative part was especially rewarding for them. On the other hand, they highly valued the practical methodology, the feeling of freedom and flexibility to be innovative in the project. It is true that sometimes they felt a little bit lost, but the tutorials were very useful and even relaxing, according to their own words. Working on long-term projects is a wonderful opportunity to promote cooperation and creativity. It also provides several moments for teachers and students to discuss together the future of education.

With regards to the use of comics in the bilingual context, it is clear that their visual support can be especially helpful for teaching and learning in a foreign language. Students did not complain about the obligation of using English during the whole project; on the contrary, they read the comics, discussed them, worked in groups and wrote their papers in English in a natural and confident way. To conclude, it is possible, and even desirable, to integrate comics and CLIL at any educational level.

\section{Conclusion}

In some ways The Tintin Project can be connected with the principles of participatory action research, which are frequently applied in university contexts as a significant methodology for intervention, development and change within educational communities. This is focused as a critical and creative response to the traditional formal models of education and it is targeted towards producing innovative guidelines for a better practice. To this respect, the cooperation between the teacher and the students is especially important with the object of promoting an educational utopia in an interactive and democratic way.

A possible limitation in the described results can be that activities are depicted in general terms but only a few are thoroughly described. Nevertheless, 
the aim of this article was to provide a global reflection about the applicability of comics in education and, more concretely, about the didactic possibilities that Herge's The Adventures of Tintin can inspire for teaching Social Sciences in bilingual contexts. Educational changes are influenced by lots of factors but one of the most relevant is methodological innovation. Comics and CLIL can give us an amazing opportunity in this sense.

It is my intention to go on with this action research line and publish new materials dealing with instructive models and specific activities in the next years. So the project is not finished yet; on the contrary it is expected to be continued.

\section{REFERENCES}

Ball, P. (2010). How do you know if you're practising CLIL? One Stop English. Retrieved from http://www.onestopenglish.com/clil/methodology/articles/ article-how-do-you-know-if-youre-practising-clil/500614.article

Barbieri, D. (1993). Los lenguajes del cómic. Barcelona, Spain: Paidós.

Barragán Gómez, R. A. (2012). Representaciones de Latinoamérica en "Las aventuras de Tintín” de Hergé. Revista de Comunicación, 10(1), 880-895.

Bitz, M. (2010). When commas meet kryptonite: Classroom lessons from The Comic Book Project. New York, NY: Teachers College Press.

Carrier, D. (2001). The aesthetics of comics. University Park, PA: Pennsylvania State University Press.

Cary, S. (2004). Going graphic: Comics at work in the multilingual classroom. Portsmouth, NH: Heinemann.

Castillo, F. (2011). Tintin - Hergé: Una vida del siglo XX. Madrid, Spain: Fórcola.

Coyle, D., Hood, P., \& Marsh, D. (2010). CLIL: Content and language integrated learning. Cambridge, England: Cambridge University Press.

Deller, S., \& Price, C. (2007). Teaching other subjects through English. Oxford, England: Oxford University Press.

Eco, U. (1995). Apocalípticos e integrados. Barcelona, Spain: Tusquets Editores. Eisner, W. (1990). Comics and sequential art. New York, NY: Poorhouse Press.

Farr, M. (2001). Tintin: The complete companion. London, England: John Murray Publishers.

Farr, M. (2007). Tintin \& Co. London, England: John Murray Publishers. Goddin, P. (2008-2011). El arte de Hergé. Barcelona, Spain: Zendrera Zariquiey. 
Gravett, P. (2005). Graphic novels: Stories to change your life. London, England: Aurum Press.

Gual Boronat, O. (2011). El cómic como fuente histórica: El falso testimonio de Tintín en el Congo Belga. Espacio, Tiempo y Forma. Serie V, Historia contemporánea, 23, 141-158.

Guiral, A. (Ed.) (2007-2012). Del tebeo al manga: una historia de los cómics. Barcelona, Spain: Panini España.

Harris, M. (1975). Cows, pigs, wars and witches: The riddles of culture. London, England: Hutchinson.

Harvey, R. C. (1994). The art of the funnies: An aesthetic history. Jackson, MI: University Press of Mississippi.

Hutchinson, K. (1949). An experiment in the use of comics as instructional material. Journal of Educational Sociology, 23, 236-245.

Jacobs, D. (2007). More than words: Comics as a means of teaching multiple literacies. English fournal, 96(3), 19-25.

Johnson, M. (2012). Bilingual degree teachers' beliefs: A case study in a tertiary setting. Pulso: Revista de Educación, 35, 49-74.

Karp, J., \& Kress, R. (2011). Graphic novels in your school library. Chicago, IL: American Library Association.

Lillo Redonet, F. (1995). Una revisión del cómic de tema clásico. Estudios Clásicos, 108, 135-145.

McCloud, S. (1993). Understanding comics: The invisible art. Northampton, MA: Kitchen Sink Press.

Mehisto, P., Marsh, D., \& Frigols, M. J. (2008). Uncovering CLIL. Oxford, England: Macmillan Education.

Meyer, O. (2010). Towards quality-CLIL: Successful planning and teaching strategies. Pulso: Revista de Educación, 33, 11-29.

Mondéjar Mateo, P. (2006). "Proyecto Asterix" para el fomento de la lectura. Premios nacionales de investigación e innovación educativa, 8, 339-360.

Ramírez, J. A. (1988). Medios de masas e historia del arte. Madrid, Spain: Cátedra.

Ravelo, L. C. (2013). The use of comic strips as a means of teaching history in the EFL class: Proposal of activities based on two historical comic strips adhering to the principles of CLIL. Latin American fournal of Content and Language Integrated Learning, 6(1), 1-19. doi:10.5294/laclil.2013.6.1.1 
Rodríguez Diéguez, J. C. (1988). El cómic y su utilización didáctica. Barcelona, Spain: Gustavo Gili.

Spiegelman, A. (1991). Maus: A survivor's tale. New York, NY: Pantheon Books.

Tomalin, B., \& Stempleski, S. (1996). Cultural awareness. Oxford, England: Oxford University Press.

Trepat, C. A., \& Rivero, P. (2010). Didáctica de la historia y multimedia expositiva. Barcelona, Spain: Graó.

Versaci, R. (2001). How comic books can change the way our students see literature: One teacher's perspective. English fournal, 91(2), 61-67.

Walqui, A. (2006). Scaffolding instruction for english language learners: A conceptual framework. The International fournal of Bilingual Education and Bilingualism, 9(2), 159-180.

Winch, G. (Ed.). (2010). Literacy: Reading, writing and children's literature. Oxford, England: Oxford University Press.

Yang, G. (2006). Comics in education. Retrieved from http://www.geneyang.com/comicsedu/ 


\section{APPENDIX}

THE TINTIN PROJECT - ASSESSMENT CHECKLIST

\begin{tabular}{|c|c|c|}
\hline \multicolumn{3}{|l|}{ STUDENTS: } \\
\hline \multicolumn{3}{|l|}{ TOPIC: } \\
\hline \multicolumn{2}{|c|}{ ITEMS TO BE CHECKED } & POINTS \\
\hline \multirow{6}{*}{$\begin{array}{l}\text { RESEARCH } \\
\text { SECTION }\end{array}$} & Introduction to the chosen comic and its topic & \\
\hline & Explanation about the most important data/features of the topic & \\
\hline & References quoted throughout the explanation & \\
\hline & $\begin{array}{l}\text { Justification for the topic to be taught to Primary Education } \\
\text { children }\end{array}$ & \\
\hline & Connection with the contents of Social Sciences & \\
\hline & Conclusion/justification for the use of comics in Education & \\
\hline \multirow{9}{*}{$\begin{array}{l}\text { DIDACTIC } \\
\text { SECTION }\end{array}$} & Title of the didactic proposal & \\
\hline & Adaptation to the target group & \\
\hline & Didactic objectives coherent and well written & \\
\hline & Connection with the official syllabus (contents and competences) & \\
\hline & Timing (general plan, didactic sequence, phases, sessions, etc.) & \\
\hline & Methodology, didactic activities, materials & \\
\hline & Language scaffolding techniques & \\
\hline & Creativity, originality, visual support & \\
\hline & Assessment plan & \\
\hline \multirow{5}{*}{$\begin{array}{l}\text { FORMAL \& } \\
\text { LANGUAGE } \\
\text { ASPECTS }\end{array}$} & Front page, font type, spacing, colours, text justifying, organization & \\
\hline & No misprints, spelling mistakes, contractions & \\
\hline & No syntax errors or incorrect language structures & \\
\hline & Bibliography, internet references (enough, appropriate, well cited) & \\
\hline & Additional information, annexes, extra material, etc. & \\
\hline & TOTAL POINTS & \\
\hline & FINAL SCORE & \\
\hline
\end{tabular}




\section{BIODATA}

Josué Llull holds a PhD in Art History from the Universidad Autónoma de Madrid and a Master's degree in Cultural Management from the Universidad de Alcalá. He has worked as a lecturer at the Cardenal Cisneros University College in Alcalá de Henares (Spain) since 1995. His teaching career is focused on the Didactics of Social Sciences, Geography and History and his current research lines deal with different topics such as Cultural Heritage and Bilingual Education. He has worked together with several Spanish publishing houses and also coordinated socio-cultural programs for a range of institutions. In 2010, he was invited to lecture in English at Duksung Women's University (Seoul, South Korea). He has also participated in other teaching and learning programs in England, Poland, and Sweden. 